\title{
CONTENTS
}

Introduction

Akin Tuncer

Eurasian decorative animal features of 'the Little Metropolis

Church of Athens'

SEVGi PARLAK

A typological evaluation of arrow slits among elements of military architecture in the medieval period

Aida Smailbegović

Infinite travel of the soul to the Sacred City and the Luminous City:

visual depictions of Mecca and Medina in Dalā'il al-Hayrāt

FATIH Elcil

Benlizâde Madrasah and its place in Ottoman architecture

JULIA KRAJCARZ

Orientalism in the Orient - elements of the Moorish style in the sacred

Muslim buildings of Istanbul

TAREK EL-AKKAD

The decline of Cairo under the Ottomans

SwietŁana Czerwonnaja

Between Kraków and Istanbul: the art and architecture of the Crimean

Khanate as the connecting link between Ottoman and European culture ....

Nuriya AKchurina-Muftieva

The Islamic tradition of building water fountains in the Crimea

KATARZYNA WARMiŃSKA

Polish and Lithuanian Tatars. One history and two stories 


\section{Piotr TAFIŁOWSKi}

The views of Erasmus of Rotterdam and his Polish followers on war

against the Turks

\section{ZÜLEYHA UsTAOĞLU}

Treaties in historical studies - the 1607 trade treaty between

the Ottoman Empire and Poland

\section{SABINE JAGODZINSKI}

European and Exotic - Jan III Sobieski's commemorative and representative strategies towards Polish-Ottoman relations

BEATA BiEdRońsKA-SŁotA

Ottoman tent from Prince Czartoryski's collection - a new look at an old tradition

\section{Hatice AdigüZel}

In search of diplomatic gifts - on a group of 18th century Polish porcelain in the Topkapı Palace collection

\section{Belgin Demirsar Arli, Şennur Kaya}

An evaluation of the architecture, culture and history of the

Polonezköy/Adampol settlement in Istanbul

ELVAN TOPALLI

Kazimierz Pochwalski’s sketchbook of Eastern travels

BogusŁaw R. ZAGóRsKi

Jean (Jan) Lambert-Rucki's artistic vision of the Ottoman women's world of Selânik

\section{Piotr TAFIŁOWSKI}

The 16th to the 18th century printed Turcica preserved in Polish

collections

\section{Piotr HoRdyński}

Diplomats, etiquette, ceremonies - the unpublished letters of Łazarz

Hordyński from the Ottoman Empire circa 1790

\section{WOJCIECH ZABŁOCKI}

My inspirations from traditional Syrian architecture 